\title{
Latar Belakang Penyakit pada Penggunaan Transfusi Komponen Darah pada Anak
}

\author{
Yetty Movieta Nency, Dana Sumanti \\ Departemen Ilmu Kesehatan Anak, Fakultas Kedokteran Universitas Diponegoro/RSUP Dr Kariadi Semarang
}

\begin{abstract}
Latar belakang. Aplikasi transfusi darah dalam klinis sehari-hari dapat sebagai terapi pengganti maupun suportif. Sesuai pertimbangan risiko dan manfaat tranfusi komponen darah seperti thrombocyt concentrate (TC) packed red cell (PRC), fresh frozen plasma (FFP), platelete rich plasma (PRP), dan cryoprecipitatel kriopresipitat lebih direkomendasikan daripada whole blood (WB).

Tujuan. Mengetahui hubungan antara latar belakang penyakit dengan penggunaan transfusi komponen darah.

Metode. Penelitian retrospekstif dilakukan di Ruang Anak Rumah Sakit Dr Kariadi Semarang. Data diperoleh dari register bank darah rumah sakit tahun 2008-2010. Latar belakang penyakit ditentukan dengan mengidentifikasi diagnosis pada setiap kasus transfusi. Komponen darah yang diteliti PRC, TC, FFP, PRP, dan kriopresipitat. Utilisasi dengan menghitung total jumlah komponen darah yang dipakai per diagnosis penyakit, dan rerata pemakaian produk darah per jumlah kasus terindikasi transfusi per tahun. Analisis uji statistik hubungan dengan menggunakan Chi square.

Hasil. Terdapat peningkatan rerata utilisasi darah 5678 unit darah per tahun. Terdapat peningkatan penggunaan selama 3 tahun terakhir, secara berurutan adalah 3751, 6496, dan 6787 unit darah $(p<0.001)$. Komponen darah yang paling banyak digunakan berturut-turut adalah TC 3228 unit, PRC 1682 unit, FFP 295 unit, PRP 224 unit, dan cryo 133 unit. Pasien leukemia merupakan pengguna komponen darah terbanyak dengan rerata pemakaian per tahun 2098 unit, diikuti oleh sepsis 893 unit, dan thalassemia 568 unit. Rasio kebutuhan PRC terbanyak untuk kasus penyakit jantung $(2,23)$ diikuti penyakit ginjal $(2,25)$ dan thalassemia $(1,7)$. Untuk penggunaan TC, terbanyak berturut-turut adalah ITP (14,70 unit), anemia aplastik ( 9,8 unit), dan leukemia (6 unit). Terdapat hubungan antara diagnosis penyakit dengan penggunaan transfusi komponen PRC, TC, dan plasma $(\mathrm{p}<0,001)$.

Kesimpulan. Terdapat hubungan antara latar belakang penyakit penyebab dengan penggunaan transfusi komponen darah. Leukemia, sepsis, dan thalassemia adalah latar belakang penyakit yang paling banyak menggunakan transfusi komponen darah. Berturut turut komponen darah yang banyak digunakan adalah konsentrat trombosit, komponen sel darah merah, serta plasma darah segar.
\end{abstract}

Sari Pediatri 2011;13(3):159-64.

Kata kunci: penyakit dasar, transfusi komponen darah

\begin{abstract}
Alamat korespondensi:
Dr. Yetty MN, Sp.A. Departemen Ilmu Kesehatan Anak FK UNDIP/ Semarang. Telp./fax.: 024-8414296. Alamat: Jl. dr Sutomo 16 Semarang. E-mail : yettymn@gmail.com
\end{abstract} ermintaan produk darah pada praktek klinis sehari hari meningkat. Tranfusi darah adalah salah satu terapi penunjang yang penting tidak hanya untuk kelainan di 
Yetty Movieta Nency dkk: Latar belakang penyakit pada penggunaan transfusi komponen darah

bidang hematologi namun juga pada kasus nonhematologi seperti sepsis, persiapan pre-operatif maupun penyakit lain. Tujuan transfusi darah antara lain untuk mengembalikan volume darah normal, mengganti kekurangan komponen darah, dan meningkatkan oksigenasi maupun hemostasis. Dasar indikasi penggunaan komponen darah selain efisien, ekonomis, juga untuk memperkecil reaksi tranfusi. ${ }^{1}$ Mengingat fungsinya sangat strategis sudah selayaknya transfusi darah dilakukan dengan hati-hati dan selalu mempertimbangan efek samping dan manfaatnya. Diketahui bahwa transfusi darah sering menimbulkan hal-hal yang merugikan karena efek-sampingnya seperti reaksi hemolitik, demam, reaksi alergi, transfusion-related acute lung injury (TRALI), transmisi penyakit menular, maupun penyebaran kanker. Oleh sebab itu indikasi transfusi darah alogenik sudah selayaknya diperketat dengan mempertimbangkan hal-hal tersebut. ${ }^{2}$

Transfusi darah yang rasional sangat penting, mengingat pemakaian produk darah telah lama diduga menyerap sumber daya kesehatan melebihi dari yang dilaporkan. Penghitungan finansial pemakaian produk darah yang tidak rasional secara langsung akan menimbulkan kesalahan yang potensial dalam pengambilan keputusan dalam sistem pelayanan kesehatan. Sebagai contoh, penghitungan biaya keseluruhan baik langsung maupun tak langsung untuk proses transfusi PRC per unit antara 522-1183 USD rerata (761 \pm 294$)$ USD. Hal ini melebihi laporan sebelumnya dan angka tersebut 3,2 - 4,8 kali lipat lebih tinggi daripada biaya penjualannya per unit. ${ }^{3}$

Dalam praktek sehari-hari banyak sekali ditemukan variasi indikasi dalam permintaan produk darah. Namun masih sering dijumpai penggunaan komponen darah tidak rasional. Kebutuhan produk darah tiap pasien sangat 'individual' dan spesifik terkait dengan situasi klinis yang dihadapi saat itu sehingga penggunaan komponen darah yang seharusnya selalu mempertimbangkan evaluasi klinis dan target apa yang diharapkan. Penggunaan produk darah yang tidak rasional dan tidak tepat indikasi akan sangat merugikan. Dampaknya tidak hanya bagi pasien tapi juga institusi penyedia darah, misalnya bukan hanya masalah efek samping tranfusi tetapi juga akan menimbulkan dampak finansial karena biaya yang tidak murah. ${ }^{4}$

Anak mempunyai kondisi fisiologis dan patologis yang berbeda dengan dewasa, dan masih banyak aspek transfusi pada anak yang belum diteliti. ${ }^{2}$ Sepengetahu- an penulis informasi mengenai pola transfusi di Indonesia masih sangat sedikit. Dengan adanya data pola tranfusi di rumah sakit akan sangat bermanfaat bagi bank darah maupun rumah sakit dalam menyusun strategi penyediaan darah maupun anggaran yang berhubungan dengan pemakaian produk darah. Penelitian bertujuan untuk mengetahui hubungan penggunaan transfusi komponen darah dengan penyakit yang mendasari.

\section{Metode}

Studi retrospektif, pada data diambil dari bank darah RS Dr Kariadi. Pasien yang dirawat di Bagian Anak pada 3 tahun terakhir (2008-2010) dikelompokkan berdasarkan diagnosis penyakit dan macam komponen darah yang digunakan. Komponen darah yang diteliti adalah packed red cell (PRC)/sel darah merah, fresh frozen plasma (FFP)/plasma segar beku, thrombocyte concentrate (TC)/konsentrat trombosit, platelet rich plasma (PRP)/plasma kaya trombosit, dan cryoprecipitate. Latar belakang penyakit yang diteliti antara lain kasus thalassemia, leukemia, hemofilia, penyakit syaraf, penyakit jantung, penyakit ginjal, sepsis, keganasan non leukemia, sindrom syok dengue (SSD), anemia aplastik, idiopathic thrombocytopenia purpura (ITP), dan persiapan operasi. Analisis uji statistik yang digunakan adalah frekuensi distribusi dan hubungan penggunaan komponen darah berdasarkan kelompok penyakit dasar dengan chi square $\left(\mathrm{x}^{2}\right)$.

\section{Hasil}

Dalam kurun waktu antara 2008 - 2010 terdapat peningkatan penggunaan komponen darah secara berurutan 3751, 6496, dan 6787 unit per tahun. Peningkatan penggunaan darah tersebut bermakna secara statistik $(\mathrm{p}<0,001)$. Jenis penggunaan masingmasing komponen darah tertera pada Tabel 1 . Tabel 1 menunjukkan komponen darah yang paling banyak digunakan adalah TC, PRC, dan FFP. Produk TC digunakan melebihi separuh dari total jumlah komponen darah. Penggunaan komponen darah berdasarkan penyakitnya tertera pada Tabel 2 .

Berdasarkan diagnosis penyakit, pasien leukemia merupakan pengguna komponen darah terbanyak dengan rerata pemakaian per tahun 2098 unit, diikuti 
Tabel 1. Komponen darah menurut distribusi tahun penggunaan

\begin{tabular}{lccccc}
\hline & \multicolumn{3}{c}{ Tahun } & & \\
\cline { 2 - 4 } Produk darah & 2008 & 2009 & 2010 & Rata-rata & $\%$ \\
\hline TC & 1821 & 3971 & 3884 & 3228 & 56,81 \\
PRC & 1217 & 1818 & 2013 & 1682 & 29,64 \\
FFP & 224 & 280 & 380 & 295 & 5,19 \\
PRP & 222 & 177 & 273 & 224 & 3,94 \\
WB & 127 & 113 & 115 & 118 & 2,34 \\
Cryo & 140 & 137 & 122 & 133 & 2,08 \\
\hline Jumlah * & 3751 & 6496 & 6787 & 5681 & 100 \\
\hline$p$ value $<0,001$ & & & & &
\end{tabular}

oleh sepsis 893 unit, thalassemia 568 unit, keganasan non- leukemia 443 unit, ITP 385 unit, anemia aplastik 330 unit, perioperatif 266 unit, sindrom syok dengue (SSD) 188 unit dan sisanya digunakan pada kasus hemofilia, penyakit jantung, penyakit ginjal, dan penyakit lainnya dengan jumlah sekitar 508 unit/tahun. Pasien leukemia, sepsis, dan ITP adalah pengguna komponen TC terbanyak. Pasien thalassemia dominan memakai PRC, diikuti oleh leukemia dan sepsis. Produk plasma PRP dan FFP paling sering digunakan oleh pasien sepsis dan kriopresipitat pada

Tabel 2. Rerata penggunaan transfusi komponen darah menurut penyakit dasar

\begin{tabular}{|c|c|c|c|c|c|c|c|}
\hline \multirow{2}{*}{ Penyakit dasar } & \multicolumn{7}{|c|}{ Rerata jumlah utilisasi (unit/ thn) } \\
\hline & WB & PRC & FFP & $\mathrm{TC}$ & PRP & Cryo & Total (unit/thn) \\
\hline Thalassemia & 0 & 539 & 5 & 24 & 0 & 0 & 568 \\
\hline Leukemia & 0 & 359 & 41 & 1681 & 18 & 0 & 2098 \\
\hline Sepsis & 20 & 206 & 44 & 476 & 144 & 3 & 893 \\
\hline Tindakan perioperatif & 38 & 160 & 29 & 29 & 2. & 7 & 266 \\
\hline Penyakit lain & 26 & 128 & 38 & 59 & 14 & 16 & 28 \\
\hline Keganasan non leukemia & 24 & 119 & 37 & 237 & 26 & 0 & 443 \\
\hline Sindrom syok dengue & 0 & 37 & 29 & 72 & 8 & 41 & 188 \\
\hline Anemia aplastik & 0 & 48 & 1 & 274 & 7 & 0 & 330 \\
\hline ITP & 0 & 16 & 5 & 353 & 5 & 5 & 385 \\
\hline Hemofilia & 0.0 & 17 & 43 & 0 & 0 & 60 & 120 \\
\hline Penyakit jantung & 11 & 35 & 20 & 16 & 0 & 0 & 82 \\
\hline Penyakit ginjal & 0.0 & 18 & 2 & 7 & 0 & 0 & 27 \\
\hline Total & 118 & 1682 & 295 & 3228 & 224 & 133 & 5681 \\
\hline
\end{tabular}

Tabel 3. Hubungan tranfusi komponen darah dengan diagnosis penyakit

\begin{tabular}{|c|c|c|c|c|}
\hline \multirow[b]{2}{*}{ Diagnosis } & \multirow{2}{*}{ Kasus* } & \multicolumn{3}{|c|}{$\begin{array}{c}\text { Rasio kebutuhan }{ }^{* *} \\
\text { Jumlah unit per tahun (unit/kasus) }\end{array}$} \\
\hline & & PRC & $\begin{array}{c}\text { Plasma } \\
(\mathrm{PRP}+\mathrm{FFP}+\text { Cryo })\end{array}$ & $\mathrm{TC}$ \\
\hline Thalassemia & 348 & 1,70 & 0,01 & 0,68 \\
\hline Leukemia & 280 & 1,28 & 0,21 & 6,00 \\
\hline Sepsis & 157 & 1,31 & 1,21 & 3,00 \\
\hline Perioperatif & 144 & 1,11 & 0,26 & 0,20 \\
\hline Penyakit lain & 118 & 1,11 & 0,57 & 0,50 \\
\hline Keganasan non leukemia & 100 & 1,19 & 0,63 & 2,37 \\
\hline DSS & 32 & 1,15 & 2,43 & 2,25 \\
\hline Anemia plastik & 28 & 1,70 & 0,28 & 9,80 \\
\hline ITP & 24 & 0,66 & 0,62 & 14,70 \\
\hline Hemofilia & 21 & 0,80 & $(4,9$ & 0 \\
\hline Penyakit jantung & 15 & 2,33 & 1,33 & 1,06 \\
\hline Penyakit ginjal & 8 & 2,25 & 0,25 & 0,87 \\
\hline p value & & $<0.001$ & $<0,001$ & $<0,001$ \\
\hline
\end{tabular}


Yetty Movieta Nency dkk: Latar belakang penyakit pada penggunaan transfusi komponen darah

kasus hemofilia.

Tabel 3 menunjukkan bahwa berdasarkan rasio kebutuhan untuk tranfusi PRC maka penyakit jantung menempati posisi teratas, memerlukan unit darah terbanyak 2,33 unit untuk setiap kasus terindikasi tranfusi diikuti oleh penyakit ginjal 2,25 unit dan thalassemia serta anemia aplastik yang memerlukan 1,7 unit per kasus terindikasi transfusi. Dalam penggunaan komponen TC, terbanyak berturut-turut kasus ITP (14,70 unit), anemia aplastik (9,8 unit) dan leukemia (6 unit). Perbedaan rasio kebutuhan ketiga komponen darah (PRC, TC, plasma) berdasarkan diagnosis penyakit yang mendasarinya didapatkan kemaknaan secara statistik dengan $\mathrm{p}<0,001$.

\section{Pembahasan}

Data maupun publikasi tentang transfusi darah terutama utilisasi komponen darah masih jarang ditemukan, maka diharapkan penelitian ini dapat memberi kontribusi. Ditemukan TC dan PRC merupakan komponen darah yang paling banyak digunakan di RS Dr Kariadi dalam 3 tahun terakhir, diikuti oleh komponen PRC dan FFP. Hal ini sesuai dengan penelitian lain di beberapa tempat bahwa PRC dan TC adalah dua produk darah yang sering dipakai. Pemakai tertinggi adalah pasien neutropenia, agranulositosis dan sickle cell crisis. Pasien onkohematologi memakai lebih dari $70 \%$ produk trombosit dan dua pertiganya digunakan untuk profilaksis perdarahan $^{5,6}$

Berdasarkan jenis penyakitnya, pasien leukemia adalah pengguna TC terbanyak diikuti oleh sepsis dan ITP. Sejak tahun 1950, TC sudah digunakan untuk terapi suportif pada kondisi mielosupresif berat seperti pada leukemia akut maupun tumor padat. Meskipun indikasi tranfusi TC bervariasi, namun penggunaannya untuk profilaksis pasca kemoterapi dosis tinggi akhirnya diperbolehkan setelah banyak data yang membuktikan bahwa tanpa adanya profilaksis TC pada acute myeloblastic leukemia (AML) 20\%-30\% akan terjadi perdarahan berat dan 34\%-58\% pada pasien pasca transplantasi alogenik. ${ }^{7,8}$

Tranfusi trombosit tidak bermanfaat pada autoimmune idiopatik thrombocytopeni purpura (AITP), drug induced thrombocytopenia, disseminated intra vascular coagulation (DIC) dan trombositopeni karena sepsis dan hipersplenisme. Untuk mengatasi trombositopeni yang terpenting adalah mengobati penyakit dasarnya. ${ }^{1}$ Beberapa senter masih mengindikasikan tranfusi TC pada kasus trombositopenia yang sangat berat dengan jumlah trombosit kurang dari $5000 / \mu \mathrm{L}$ yang disertai dengan perdarahan spontan. Pada beberapa kepustakaan disebutkan bahwa indikasi transfusi trombosit antara lain, perdarahan akibat trombositopenia, profilaksis pada pasien dengan kegagalan sumsum tulang (anemia aplastik, leukemia), dan profilaksis pada tindakan bedah. ${ }^{1,9}$

Masih ditemukan banyak sekali variasi dalam hal indikasi transfusi baik pada trombosit maupun sel darah merah, untuk itu diperlukan penelitian prospektif tersamar untuk menghasilkan petunjuk berbasis bukti. ${ }^{4,10,11}$ Pada studi kami terlihat kasus ITP mempunyai rasio kebutuhan tertinggi, yaitu setiap kasus terindikasi transfusi rata-rata memerlukan trombosit 14,7 unit. Hal ini memerlukan telaah lebih lanjut, salah satunya dengan mengevaluasi ulang riwayat indikasi dilakukannya tranfusi TC pada ITP kasus demi kasus.

Temuan terbaru melaporkan bahwa batas jumlah trombosit untuk profilaksis apabila kurang dari $10.000 / \mu \mathrm{L}$ demikian juga untuk tindakan terapi masih akan aman untuk derajat tersebut. Penelitian lain mengemukakan bahwa dosis rendah TC (hampir sama dengan separuh unit dari hasil aperesis atau 2-3 unit darah lengkap) sama efektifnya dalam mencegah perdarahan pada pembedahan dibandingkan dengan dosis yang lebih tinggi. Sampai saat ini belum ada penelitian random tentang batasan jumlah trombosit untuk tindakan invasif maupun operasi mayor. Batasan $50.000 / \mu \mathrm{L}$ sebenarnya hanya berdasarkan pengalaman klinis dan data observasional yang mengindikasikan bahwa jumlah trombosit melebihi jumlah tersebut tidak ada manfaatnya. Optimalisasi transfusi trombosit adalah penting bukan hanya untuk pasien tapi juga penting dalam hal finansial. Edukasi berbasis bukti akan sangat mengurangi transfusi TC dan menekan biaya perawatan. ${ }^{11,12}$

Penyediaan produk untuk transfusi trombosit memerlukan sumber logistik yang baik dan mempertimbangkan faktor biaya. Kesulitan menjaga ketersediaan TC membutuhkan usaha untuk mencari banyak donor. Salah satu strategi dalam optimalisasi transfusi trombosit adalah dengan penggunaan filter. Pemisahan leukosit dari berbagai komponen darah telah menunjukkan keberhasilannya dalam meminimalis reaksi transfusi seperti demam, HLA 
aloimunisasi dan trombositopeni yang refrakter. Seiiring dengan meningkatnya jumlah pasien hematoonkologi yang memerlukan transfusi multipel mereduksi leukosit sampai di bawah kadar 5 X $10^{6} /$ $\mu \mathrm{L}$ akan sangat membantu. Saat ini cara terbaik untuk reduksi leukosit adalah dengan bantuan leukofilter generasi ke 3 dan $4 .{ }^{13}$

Transfusi sel darah merah seharusnya diindikasikan untuk mengganti darah atau mempertahankan kadar oksigen normal yang diedarkan ke organ dan jaringan. Akhir- akhir ini dengan mempertimbangkan risiko transfusi dan biaya maka diusahakan untuk membatasi penggunaan produk darah. Keseimbangan antara risiko dan manfaat transfusi menjadi sangat kompleks ketika pembatasan transfusi berhasil mengurangi efek samping transfusi yang tidak dikehendaki dan dapat menekan biaya, tetapi di lain pihak akan ada risiko gangguan transpor oksigen. Mayoritas transfusi PRC tidak diberikan pada kadar hemoglobin lebih dari 8 $\mathrm{mg} / \mathrm{dl} .{ }^{1,2,9}$

Temuan menarik pada studi kami adalah berdasarkan rasio kebutuhan penyakit jantung dan ginjal menempati posisi pemakai PRC terbanyak pada setiap kasus terindikasi tranfusi, namun hal ini harus dievaluasi lebih lanjut karena jumlah subyek penelitian yang kecil dibandingkan kasus thalassemia ataupun anemia aplastik.

Pada pasien kanker sering timbul anemia yang dengan mudah dapat diatasi dengan transfusi. Pada penelitian lain dengan subyek 219 pasien kanker memerlukan transfusi rata-rata setiap pasien 3,71 unit PRC. ${ }^{14}$ Pada penelitian kami setiap pasien leukemia terindikasi tranfusi memerlukan 1,28 unit PRC, dan 6 unit untuk TC. Leukemia juga memakai lebih dari separuh (52\%) produk TC dan menempati posisi kedua sebagai pengguna PRC. Hal ini disebabkan bukan hanya karena mielosupresi akibat penyakit dasarnya melainkan juga karena proses terapinya dengan sitostatika jangka lama. Pada penelitian multivariat pasien acute lymphoblastic leukemia (ALL), jumlah produk darah (PRC dan TC) yang ditranfusikan berhubungan secara bermakna dengan menurunnya survival time karena hal ini mencerminkan derajat beratnya penyakit. ${ }^{15}$

Hal-hal penting yang harus dilakukan dalam unit transfusi adalah staf yang mengetahui manajemen darah, pencatatan riwayat tranfusi, dan kerja sama yang baik dengan bank darah. Jumlah tranfusi PRC dan TC dihubungkan dengan protokol terapi. Namun kadar yang lebih rendah tidak menyebabkan komplikasi dalam pengobatan, untuk itu perlu adanya penelitian untuk menetapkan kriteria yang optimal untuk terapi suportif transfusi pada kasus kanker anak. ${ }^{4,16}$

Dalam hal transfusi plasma, pada studi ini melaporkan bahwa pasien dengan sepsis, DSS, dan hemofilia adalah pengguna terbanyak. Kasus hemofilia dominan menggunakan kriopresipitat. Rasio kebutuhan kriopresipitat didapatkan angka yang cukup tinggi (4,90 unit) tiap kasus terindikasi tranfusi, hal ini dapat dikurangi dengan penggunaan faktor VIII konsentrat. Penelitian multisenter tentang penggunaan FFP di Inggris pada tahun 2010, menyebutkan bahwa tranfusi FFP sebagian besar dilakukan pada unit rawat intensif, ruang operasi, ruang pemulihan maupun bangsal perawatan. Banyak sekali variasi ditemukan rasio waktu protombin yang digunakan sebelum memutuskan pemberian transfusi FFP. Pada pasien dengan tujuan transfusi adalah untuk profilaksis sebelum adanya perdarahan maka banyak dipakai rasio 1,5 (dibandingkan harga normal). Perubahan kadar koagulasi setelah pemberian FFP pada anak dan dewasa sebenarnya sangat sedikit. Sehingga layak dipertanyakan manfaat klinis penggunaan FFP dan menekankan perlunya penelitian untuk mengevaluasi secara kualitatif efek transfusi plasma terhadap tes koagulasi. ${ }^{17}$

\section{Kesimpulan}

Terdapat hubungan antara latar belakang penyakit dengan penggunaan transfusi komponen darah. Keganasan leukemia, sepsis, dan thalassemia adalah latar belakang penyakit yang paling banyak memakai komponen darah. Berturut-turut komponen darah yang banyak digunakan trombosit konsentrat, komponen sel darah merah, serta plasma darah segar. Perlu dibuat guideline/petunjuk indikasi tranfusi yang tepat untuk mengurangi tindakan tranfusi darah yang tidak rasional dan pencatatan mengenai indikasi transfusi darah dan efikasinya.

\section{Daftar pustaka}

1. Sudarmanto B, Tamam M, Soemantri Ag. Transfusi darah dan transplantasi. Dalam: Permono B, Sutaryo, Ugrasena, penyunting. Buku ajar hematologi-onkologi anak. Jakarta: BP IDAI; 2005.h.217-26. 
Yetty Movieta Nency dkk: Latar belakang penyakit pada penggunaan transfusi komponen darah

2. Morley SL. Red blood cell transfusions in acute pediatrics. Arch Dis Child Educ Pract Ed 2009;94:65-73.

3. Shander A, Hofmann A, Ozawa S. Theusinger O, Gombotz H, Spahn DR. Activity-based costs of blood transfusions in surgical patients at four hospitals. Transfusion 2010;50: 753-65.

4. Josephson CD, Su Li, Christesen RD. Platelet transfusion practices among neonatologists in the United States and Canada: results of a survey. Pediatrics 2009;123:27885.

5. Slonim AD, Joseph JG, Turenne WM, Sharangpani A, Luban NL. Blood transfusions in children: a multiinstitutional analysis of practices and complications. Transfusion.2008;48:73-80.

6. Bosch MA, Contreras E, Madoz P, Ortiz P, Pereira A, Pujol MM. The epidemiology of blood component transfusion in Catalonia, Northeastern Spain. Transfusion 2011;51:105-16.

7. Buhrkuhl D. An update on platelet transfusion in hemato-oncology supportive care. Transfusion 2010;50:2266-76.

8. Heim D, Passweg J, Gregor Ml. Patient and product factors affecting platelet transfusion results. Transfusion 2008; 48:681-87.

9. Mc Clelland DBL. Hand book of transfusion. united kingdom blood service. Edisi ke-4. 2007:18-35.

10. Spinella PC, Dressler A, Tucci M. Survey of transfusion policies at US and Canadian children's hospitals in 2008 and 2009. Transfusion 2010;50:2328-35.

11. Sarode R, Refaai MA, Matevosyan K, Burner JD, Hampton S. Rutherford C. Prospective monitoring of plasma and platelet transfusions in a large teaching hospital results in significant cost reduction. Transfusion 2010;50:487-92.

12. Blumberg N, Heal JM, Philips GL. Platelet transfusions: trigger, dose, benefits, and risks. Medicine Reports 2010;27;2-5.

13. Sharma RR, Neelam M. Leukoreduced blood components: advantages and strategies for its implementation in developing countries. Asian J Transfusions Sci 2010;4:3-8.

14. Paananen P, Miko OA, Pelliniemi TT. Evaluation of the effects of different transfusion trigger levels during the treatment of childhood acute lymphoblastic leukemia. Journal of Pediatr Hematol/Oncol 2009 ;31:745-49.

15. Jaime PJ, Colunga PP, Gómez-Almaguer D. Is the number of blood products transfused associated with lower survival in children with acute lymphoblastic leukemia? Pediatr Blood Cancer 2011;1:16.

16. Fuller AK, Uglik KM, Braine HG,King KE. A comprehensive program to minimize platelet outdating. Transfusion, 2010:44:56-19.

17. Stanworth SJ. Grant CJ, Lowe D, Laffan MN, Murphy MF, Allard S. The use of fresh-frozen plasma in England: high levels of inappropriate use in adults and children. Transfusion 2011;51:62-70. 